\title{
"Yellow Araçá" flour (Psidium cattleyanum cv. Ya-cy) in cereal bars - nutritional and functional potential
}

\author{
Camila Da Rosa VANIN ${ }^{1}$, Ronaldo Follmann dos SANTOS ${ }^{1}$, Ivane Benedetti TONIAL ${ }^{1 *}$ (D), Tatiane Batista dos \\ SANTOS $^{1}$, Américo WAGNER JUNIOR ${ }^{1}$, Naimara Vieira do PRADO ${ }^{1}$, Luciano LUCCHETTA ${ }^{1}$
}

\begin{abstract}
Yellow Araçá (Psidium cattleyanum cv. Ya-cy) is a Brazilian native fruit that can be consumed fresh or turned into food products. However, distribution and consumption of fresh fruits are still limited due to faulty post-harvest handling. Thus, the present study aimed to evaluate the nutritional and functional potential of fresh Yellow Araçá fruit, turned into flour, in formulations of cereal bars. Ripe fruits preserved higher nutritional and functional indexes, presenting high antioxidant potential. As observed during the sensory analysis, addition up to $20 \%$ of fruit flour into the cereal bar was well accepted by the consumers. The cereal bar showed significant levels of omega-6 (n-6) and omega-9 (n-9), and minerals nutrients such as iron, magnesium, potassium, zinc. Significant levels of phenolic compounds and low levels of sodium and saturated fatty, free from trans fatty acids, were also observed. The cereal bar presented high amount of crude fiber content, indicating a high potential for use as a functional food.
\end{abstract}

Keywords: fruit; natural antioxidants; nutraceuticals; food preservation and processing; cereal processing.

Practical Application: Utilization of native fruit, Yellow Araçá flour, in the processing in cereal bar.

\section{Introduction}

Brazil is a country of abundant territorial extension, standing out for the diversity of native plant species. However, only few species of fruits are explored and commercialized fresh or turned into industrialized products. This fact can be associated with high perishability of fruits, and logistics for industrialization and distribution. Several studies indicate that fruit consumption, in general, can help in the prevention of chronic-degenerative diseases, such as cancer, cardiovascular diseases, diabetes and neurodegenerative diseases (Santos \& Meireles, 2009; Boffetta et al., 2010, Veggi et al., 2011; Cavalcanti et al., 2011).

Yellow Araçá is a Brazilian native fruit that presents nutritional and functional potential, with significant capacity of antioxidant activity due to its large amount of phenolic content (Medina et al., 2011). This fruit has an exotic flavor, widely accepted by consumers, with significant levels of vitamin and nutrients (Damiani et al., 2012, Neri-Numa et al., 2013). This fruit is generally consumed fresh, however, due to its high perishability (two to three days postharvest), processing remains as viable alternative to make it available to consumers in any region, at any time, in the form manufactured food (Medina et al., 2011; Damiani et al., 2012).

Dehydration, or drying process, has been used by food industries to turn fruits into flour, offering the consumer a product of good nutritional and sensory quality (Fasolin et al., 2007; Marquetti et al., 2018; Assis et al., 2019). Considering conservation limits, due to the short post-harvest life caused by the high moisture content and sensitivity of its pericarp, yellow araça is an interesting raw material for processing differentiated flour, providing nutritional and bioactive properties with health benefits through antioxidant compounds.

Fruit flours can be applied into various food matrices such as bread, cakes, ice creams, cookies, cereal bars, among others, with considerable addition of bioactive compounds. Studies report that by-products of tropical fruits such as pineapple, passion fruit and mango present high potential to be used as a functional ingredient. Providing dietary fiber (for nutritional and technological purposes) and/or natural antioxidants to special foods with health appeal, like cereal bar and cookie (Ajila \& Prasada Rao, 2013; Selani et al., 2014, 2016; Toledo et al., 2017).

Cereal bars constitute a differentiated category of food products, serving various segments of consumers seeking a healthy diet. Cereal bars, while promoting health benefits, are pleasant to the taste and this favored their consumption (Oliveira et al., 2018). Therefore, the present study aimed to produce and evaluate cereal bars formulated with Yellow Araçá flour (Psidium cattleyanum cv. Ya-cy), in order to enhance their nutritional and functional quality.

\section{Materials and methods}

\subsection{Sample collection}

Fresh fruits of yellow araçá (Psidium cattleyanum cv. Ya-cy) were obtained from the orchard located in the didactic station at Universidade Tecnológica Federal do Paraná (UTFPR) - Campus 
Dois Vizinhos, Paraná State, Brazil (2541'48.0”S; 5305’37.1”W, $650 \mathrm{~m}$ altitude, under subtropical climate). The fruits were harvested and placed into polystyrene packages for later transport to UTFPR - Campus Francisco Beltrão, Paraná State, Brazil, where the analyses were performed.

In the Laboratory at UTFPR - Campus Francisco Beltrão, the fruits were classified according to the ripening stage in unripe (green color) and ripe (yellow color). Both, unripe and ripe whole fruits were submitted to physical and chemical characterization analyses. Fruits were placed for thirty minutes into a sodium hypochlorite solution ( $\left.50 \mathrm{mg} \cdot \mathrm{L}^{-1}\right)$ for sanitization. The ripe and unripe fruits were divided into two groups: two-third of the fruits underwent the dehydration process and other one-third remaining was frozen at $-18^{\circ} \mathrm{C}$ for subsequent characterization analyses.

\subsection{Flour preparation}

Prior to flour preparation, the fruits were cut into four equal parts. Each part was packed in aluminum trays and placed in a forced-air oven at $70^{\circ} \mathrm{C}$, until reaches a moisture content below $25 \%$. To obtain the flour, after drying, the fruits were crushed in a commercial food multiprocessor and sieved (mesh 8). The flour produced were then stored into vacuum plastic bags and frozen $\left(-18^{\circ} \mathrm{C}\right)$.

\subsection{Cereal bar preparation}

The cereal bars were elaborated with the addition of yellow araça flour according to the formulation recipe adapted from Freitas \& Moretti (2006). Pre-tests were performed to establish the amount of flour to be added in the formulations. As observed, $20 \%$ of the total volume of the cereal bar was the maximum of araçá flour that could be used without negative interference in the sensorial and technological characteristics of the final product. Defined the percentage limited of flour to be added in the formulations, an experimental factorial design was applied, two factors by two levels $\left(2^{2}\right)$.

The amount of yellow araçá flour and amount of oat flakes established the factors, with minimum $(-1)$ and maximum $(+1)$ levels, plus the central point performed in triplicate (Table 1).

The ingredients used to formulate the cereal bars were purchased from the local market, except the yellow Araçá flour. The bars were prepared in the processing Laboratory at the UTFPR Sensory Analysis Laboratory, Câmpus Francisco Beltrão. The syrup solution was prepared by adding all the ingredients (crystal sugar, glucose syrup, vegetable fat and water) in a stainless-steel jar and heated until reach $100{ }^{\circ} \mathrm{C}$.

The soluble solids concentration was measured until reaches the range of $82{ }^{\circ} \mathrm{Brix}$ to $86^{\circ} \mathrm{Brix}$, when the prepared syrup solution was then added to the pre-blended dry ingredients (Araçá flour, oat flakes, soybean textured protein and lecithin). The formulations were prepared, pressed and, after 24 hours, cut and packed using flexible films intended for food (PVC, plasticized, polyvinyl chloride) (Table 1).
Table 1. Factorial design used to define and formulate the cereal bars added with different percentages of yellow araçá flour (Psidium cattleyanum cv. Ya-cy) and ingredients used in formulations.

\begin{tabular}{|c|c|c|c|c|c|}
\hline \multirow{2}{*}{ Trataments ${ }^{*}$} & \multirow{2}{*}{$\begin{array}{c}\text { Araçá } \\
\text { flour } \\
(\%)\end{array}$} & \multirow{2}{*}{$\begin{array}{c}\text { Oats } \\
\text { flakes } \\
(\%)\end{array}$} & \multicolumn{3}{|c|}{ Levels } \\
\hline & & & & Araçá & Oats \\
\hline $\mathrm{T} 1$ & 10 & \multicolumn{2}{|l|}{10} & -1 & -1 \\
\hline $\mathrm{T} 2$ & 20 & \multicolumn{2}{|l|}{10} & +1 & -1 \\
\hline $\mathrm{T} 3$ & 10 & \multicolumn{2}{|l|}{15} & -1 & +1 \\
\hline $\mathrm{T} 4$ & 20 & \multicolumn{2}{|l|}{15} & +1 & +1 \\
\hline $\mathrm{Cp}$ & 15 & \multicolumn{2}{|l|}{12.5} & $\mathrm{Cp}$ & $\mathrm{Cp}$ \\
\hline $\mathrm{Cp}$ & 15 & \multicolumn{2}{|l|}{12.5} & $\mathrm{Cp}$ & $\mathrm{Cp}$ \\
\hline Cp & 15 & \multicolumn{2}{|l|}{12.5} & Cp & Cp \\
\hline \multirow{2}{*}{ Ingredients } & \multicolumn{5}{|c|}{ Formulation (g.100g $\left.\mathrm{g}^{-1}\right)$} \\
\hline & $\mathrm{F} 1$ & F2 & F3 & $\mathrm{F} 4$ & F5 \\
\hline \multicolumn{6}{|l|}{ Moist Ingredients } \\
\hline Crystal Sugar & 25.0 & 25.0 & 25.0 & 25.0 & 25.0 \\
\hline Glucose syrup & 10.0 & 10.0 & 10.0 & 10.0 & 10.0 \\
\hline Vegetable fat & 2.0 & 2.0 & 2.0 & 2.0 & 2.0 \\
\hline Water & 23.0 & 13.5 & 13.5 & 13.5 & 16.0 \\
\hline \multicolumn{6}{|l|}{ Dry Ingredients } \\
\hline Araçá flour & 10.0 & 20.0 & 10.0 & 20.0 & 15.0 \\
\hline Oats flakes & 10.0 & 10.0 & 15.0 & 15.0 & 12.5 \\
\hline Textured Soy Protein & 15.0 & 15.0 & 15.0 & 10.0 & 15.0 \\
\hline Soy lecithin & 5.0 & 4.5 & 4.5 & 4.5 & 4.5 \\
\hline
\end{tabular}

\subsection{Analyses}

\section{Proximate composition characterization}

The analyzes of moisture, protein and ash content, and total acidity were performed according to analytical procedures proposed by AOAC (Association of Official Analytical Chemists, 2010). The determination of lipid content was performed according the method proposed by Bligh \& Dyer (1959). The carbohydrate and energy value analysis were performed as proposed by Osborne \& Voogt (1978). Total carbohydrates were calculated by difference, subtracting the other components, and the caloric value was determined applying the Atwater conversion factors. The results were expressed on a wet basis.

\section{Fatty acids profile characterization}

Fatty acids were determined by gas chromatograph (Varian model 3900), equipped with a flame ionization detector (FID), workstation with STAR software and split injector, with a sample split ratio of 75:1. A ZB-WAX capillary column, $60 \mathrm{~m}$ long and $0.25 \mathrm{~mm}$ of internal diameter, with $0.25 \mu \mathrm{m}$ film thickness, was used. Hydrogen was used as the carrier gas, at a flow rate of $2 \mathrm{~mL}$ minute $^{-1}$, and nitrogen as the make-up gas, at a flow rate of $25 \mathrm{~mL}$ minute ${ }^{-1}$, with an injector temperature of $270{ }^{\circ} \mathrm{C}$, 
detector temperature of $300^{\circ} \mathrm{C}$ and volume of injection of $1 \mu \mathrm{L}$ (Association of Official Analytical Chemists, 2010).

The identification of fatty acids was performed by comparing the retention times of fatty acids from samples and standards. A total of thirty-seven fatty acid methyl esters were used for the identification of fatty acids (Supelco IM 37 Component FAME Mix by Sigma-Aldrich), by normalizing the fatty acid peaks areas (in percentage) for presentation of their results.

\section{Quantification of bioactive compounds}

The total phenols were determined at a wavelength of $765 \mathrm{~nm}$, as described by Folin-Ciocalteau (Singleton et al., 1999), and the results expressed in GAE - Gallic Acid Equivalent $\left(\mathrm{g} \mathrm{GAE} 100 \mathrm{~g}^{-1}\right)$. The methodology described by Zhishen et al. (1999) was used to analyze the total flavonoids, and the extract reading was performed at $510 \mathrm{~nm}$. The results were expressed in $\mathrm{mg}$ of catechin equivalents (CE) per $100 \mathrm{~g}$ of the fruit.

The antioxidant activity potential was determined by DPPH (2,2-diphenyl-1-picryl-hydrazyl), with values expressed in EC50 (g fruit $\mathrm{g} \mathrm{DPPH}^{-1}$ ), according to Brand-Williams et al. (1995), adapted by Rufino et al. (2007). The Ferric Reducing Antioxidant Power (FRAP) was measured according to Rufino et al. (2006), read in a spectrophotometer to a wavelength of $595 \mathrm{~nm}$, with the results being expressed in $\mu \mathrm{M}$ FeSO $4 \mathrm{~g}^{-1} \mathrm{FW}$. These results were used to determine which flours (unripe or ripe fruit) would be added to the formulations.

\section{Sensory analysis}

The sensorial analysis was conducted after approval by the UTFPR Research Ethics Committee (CAAE 42177715.0.0000.5547), and the microbiological evaluation (thermal tolerant coliforms, Bacillus cereus e Salmonella spp), which attested the safe condition of the samples.

To assess the acceptance of the cereal bar with araçá flour by consumers, affective preference and acceptance tests were applied for evaluate the global appearance, color, flavor, aroma and texture attributes, in addition to the purchase intention test. In the tests of preference and acceptance, a hedonic scale of 9 points was used, ranging from like extremely to dislike extremely. In the purchase intention test, a hedonic scale with five points was used, ranging from 1 "certainly would not buy" to 5 "certainly would buy". One hundred untrained volunteer panelists signed a free informed term of consent (FITC), following recommendations and guidelines of Resolution 466/2012 of the Brazilian Ministry of Health on ethical aspects (Brasil, 2012).

The formulation with the best acceptance in the sensory evaluation was subjected to physical-chemical characterization - Moisture, ash, lipid, total dietary fiber, protein and total carbohydrates content (Association of Official Analytical Chemists, 2010).

\section{Data analyses}

The data obtained from the analyzes of moisture, ash, acidity, proteins, lipids, antioxidant potential and phenolic compounds were subjected to the normality test, analysis of variance (ANOVA) and to the Tukey test using Statistica 7.0 software (test version). The total flavonoids were analyzed by the Genes software ${ }^{\circledR}$, to verify normality (Lilliefors test) and Sanest software ${ }^{\circledR}$, whose standardized data considered non-normal (by equation) and applied Duncan test at $5 \%$ significance level $(\mathrm{p}<0.05)$. In the sensory analysis, to access the main components, the data were interpreted by programs XLSTAT (Addinsoft, 2015) and MS Excel, version 2013, with the free supplement ACTION $2.3^{\circledR}$.

\section{Results and discussion}

\subsection{Physical-chemical characterization, bioactive compounds and antioxidant potential of unripe and ripe yellow araçá fresh fruit and flour}

The physical-chemical results of fresh and dehydrated fruits, in the unripe and ripe forms, did not show significant difference $(\mathrm{p}<0.05)$, as shown in Table 2. Bioactive compounds, at the same stage of maturation, differed significantly in the amount of flavonoids and antioxidant potential via FRAP ( $p<0.05)$, whereas for dehydrated fruits none of the bioactive compounds were significantly influenced ( $\mathrm{p}>0.05$ ) (Table 2).

When dehydrated, the reduction in the percentage of moisture content in yellow araçá fruits varied from $65.29 \%$ (immature or unripe) to $66.14 \%$ (mature or ripe), contributing to elevate the concentration of other components. After the dehydration process (reaching approximately 15\% of moisture content), yellow araçá can be used in the manufacturing of food formulations, providing stability and increasing characteristic components of this fruit.

The total mineral content (ash) did not differ significantly between unripe and ripe fruits of yellow araçá, within fresh and dehydrated form ( $p>0.05)$. However, when dehydrated, the variation was four times greater when compared fresh and dehydrated fruits (Table 2). These indices are highly positive, considering its maintenance and concentration in the fruits during the dehydration process. Minerals are compounds of great importance to maintain the activities of the human organism (Granato et al., 2009).

Products of plant origin normally present low percentage of protein, as showed in Table 2, fresh araçá fruits and its dry flour form presented protein content with values varying from 2.42 to $6.00 \%$, similar to the values obtained by Dalla Nora et al. (2014), evaluating red araçá (3.77\%). This content observed is considered median when compared to other plants used as a source of protein.

The lipid content observed in the fresh fruit and flour were low, ranging from 0.71 to $1.51 \%$. As expected, araçá is not a great source of lipids, even if dried and turned into flour. In the flour, the content of lipids is comparable to the ones reported by Pereira et al. (2012) (1.53\%), but higher than the value reported by Canuto et al. (2010) (0.30\%). From a nutritional point of view, lipids and proteins have significant importance, however, as in most vegetables, these rates are below the daily needs indicated for human consumption.

The total carbohydrate was difference $(\mathrm{p}<0.05)$ comparing the content in fresh fruit and in its dry flour, the latter value being 5 times higher than that found in fresh fruit. The caloric 
Table 2. Physical-chemical characterization, bioactive compounds and antioxidant potential of unripe and ripe yellow araçá fresh fruit and flour.

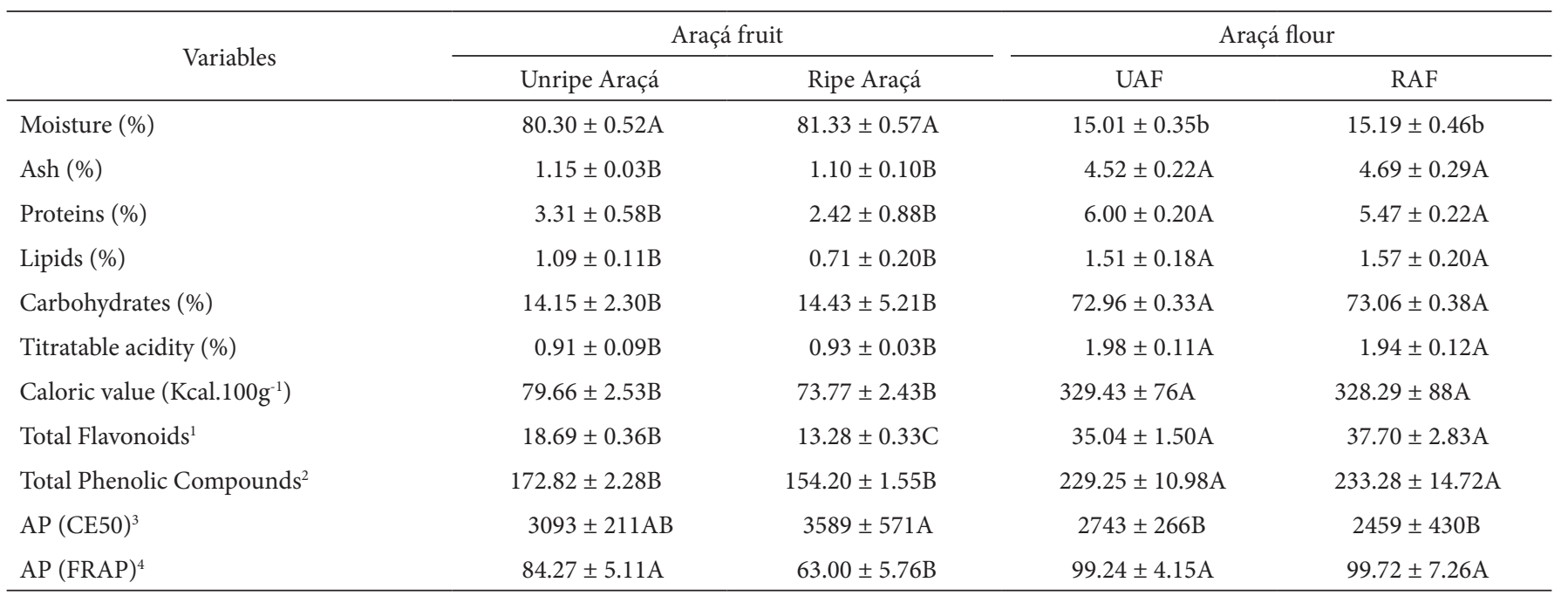

UAF: Unripe Araça Flour; RAF: Ripe Araça Flour. Mean rates $(\mathrm{n}=3)$ followed by their standard deviation; ${ }^{1}$ Catechin Equivalent. 3 mg of cyanidin-3-glucoside 100 g flour ${ }^{1} ;{ }^{2}$ mg GAE g flour-1; ${ }^{3}$ Antioxidant Potential (CE50) (g fruit or flour. g DPPH); ${ }^{4}$ Antioxidant Potential. FRAP: Ferric Reducing Antioxidant Power ( $\mu$ M ferrous sulphate/g fruit or flour); Means followed by the same capital letter in the same line do not statistically differ at $5 \%$ probability by Tukey test.

value of yellow araçá remained stable with the ripening stage, for fresh fruit and flour $(\mathrm{p}>0.05)$. However, comparing fresh fruit with flour, without considering the maturation stage, the caloric value of the flour was approximately four times greater than the one observed in the fresh fruit, resulted from the concentration of components, due to water loss occurred during dehydration process. The high percentages of carbohydrates found in the flours can be of great benefit, since these indices can contribute to the energetic enrichment of foods through addition.

The total titratable acidity considers the major acids present in fruits, being directly related to the maturity stage. However, as shown in Table 2, the variation in the percentage of acidity did not differ statistically $(p>0.05)$ in fresh fruit (unripe and ripe), as well as in flours (Flour of unripe araça - FUA and and flour of ripe araçá - FRA). As expected, total titratable acidity, proteins, lipids, total carbohydrates and caloric value increased significantly with the dehydration process of the fruits.

The content of flavonoids and phenolic compounds were higher in unripe yellow araçá (fresh) when compared to the ripe ones (Table 2). In the maturation process, as expected due to the metabolism and transformation processes, a significant decrease in the concentration of flavonoids was observed, which significantly changed its quantity in the fruits $(\mathrm{p}<0.05)$. The difference between unripe and ripe fruits was also described by Dantas et al. (2013), observing a concentration of $1.56 \mathrm{mg} .100 \mathrm{~g} \mathrm{~g}^{-1}$ in unripe fruits and $3.56 \mathrm{mg}^{100 \mathrm{~g}^{-1}}$ in the ripe ones. The development of maturation process can explain this behavior, with polymerization of phenolic molecules, predominating in immature or unripe fruits. Considering the accumulation of phenolic compounds, due to the dehydration process, ripe fruits are the best option for preparing the flour, once the concentration of these compounds are $52 \%$ higher, compared to the unripe ones. According to Cataneo et al. (2008), after subjecting the fruits to heat treatment, occurs the conversion of insoluble phenolic compounds into the soluble ones, without breaking their covalent bonds.
The Araçá flour showed high antioxidant potential (Table 2). These results are very interesting as they show a potential natural ingredient, which can be used to aggregate value in the processing of healthy foods and special appeals. The antioxidant capacity in fresh fruits was higher than the observed by Dalla Nora et al. (2014) (16713.2 g.g-1 DPPH). The values obtained were lower than those presented by Dantas et al. (2013) and Pereira et al. (2012) for yellow and red Araçá, respectively. The drying process, and subsequent processing into flour, affected the antioxidant potential of yellow araçá, increasing its concentration by $31.5 \%$ and $11.3 \%$ after drying ripe and unripe fruits, respectively.

According to Lim \& Murtijaya (2007), an increment in the antioxidant capacity and phenolic compounds content were also observed in some processed foods. The manufacturing process and/or prolonged storage time can promote or progressive enhance the enzymatic and/or chemical transformations. However, this fact is dependent of some intrinsic variables as well as on the processing conditions, storage time and packaging method of the foods (Queiroz et al., 2011).

\subsection{Cereal bars sensory analysis}

After the initial characterization of the yellow araça flour, it was used to develop a cereal bar based on a factorial design $2^{2}$ (Table 1). The cereal bars developed were then subjected to sensory evaluation to select the most acceptable formulation by the panelists and, finally, to evaluate its nutritional and chemical characteristics.

The Table 3 shows the scores assigned by the panelists to the formulated cereal bars. There was no significant difference among the formulations for attributes such as color, flavor, aroma, and overall appearance $(p>0.05)$. The only significant changes observed were in texture and preference test, with formulation $\mathrm{F} 4(20 \%$ of FA) receiving the highest scores $(\mathrm{p}<0.05)$.

The sensory behavior is better explored when the data is presented in a principal components structure (Figure 1). There is 
Table 3. Sensory analysis, preference test and purchase intention of cereal bars added with yellow araçá flour.

\begin{tabular}{|c|c|c|c|c|c|}
\hline \multirow{2}{*}{ Attributes } & \multicolumn{5}{|c|}{ Samples } \\
\hline & F1 & $\mathrm{F} 2$ & F3 & $\mathrm{F} 4$ & F5 \\
\hline Color & $7.92 \mathrm{~A}$ & $7.93 \mathrm{~A}$ & $7.52 \mathrm{~A}$ & $7.57 \mathrm{~A}$ & $7.59 \mathrm{~A}$ \\
\hline Flavor & $7.21 \mathrm{~A}$ & $7.19 \mathrm{~A}$ & $7.32 \mathrm{~A}$ & $7.35 \mathrm{~A}$ & $7.20 \mathrm{~A}$ \\
\hline Aroma & $6.98 \mathrm{~A}$ & $7.04 \mathrm{~A}$ & $7.12 \mathrm{~A}$ & $7.10 \mathrm{~A}$ & $7.16 \mathrm{~A}$ \\
\hline Texture & $6.87 \mathrm{AB}$ & $6.58 \mathrm{~B}$ & $6.79 \mathrm{AB}$ & $7.33 \mathrm{~A}$ & $6.88 \mathrm{AB}$ \\
\hline Overall Appearance & $7.53 \mathrm{~A}$ & $7.26 \mathrm{~A}$ & $7.29 \mathrm{~A}$ & $7.38 \mathrm{~A}$ & $7.24 \mathrm{~A}$ \\
\hline Preference Test & $2.81 \mathrm{AB}$ & $3.08 \mathrm{AB}$ & $2.98 \mathrm{~A}$ & $2.72 \mathrm{~A}$ & $3.35 \mathrm{~B}$ \\
\hline Test $\mathrm{PI}^{*}$ & $3.73 \mathrm{~A}$ & $3.59 \mathrm{~A}$ & $3.62 \mathrm{~A}$ & $3.65 \mathrm{~A}$ & $3.45 \mathrm{~A}$ \\
\hline
\end{tabular}

${ }^{*}$ Purchase Intent. Means of sensory scores with 100 consumers; Means of the same capital letter in the same columns do not statistically differ at $5 \%$ probability by Kruskall-Wallis test.

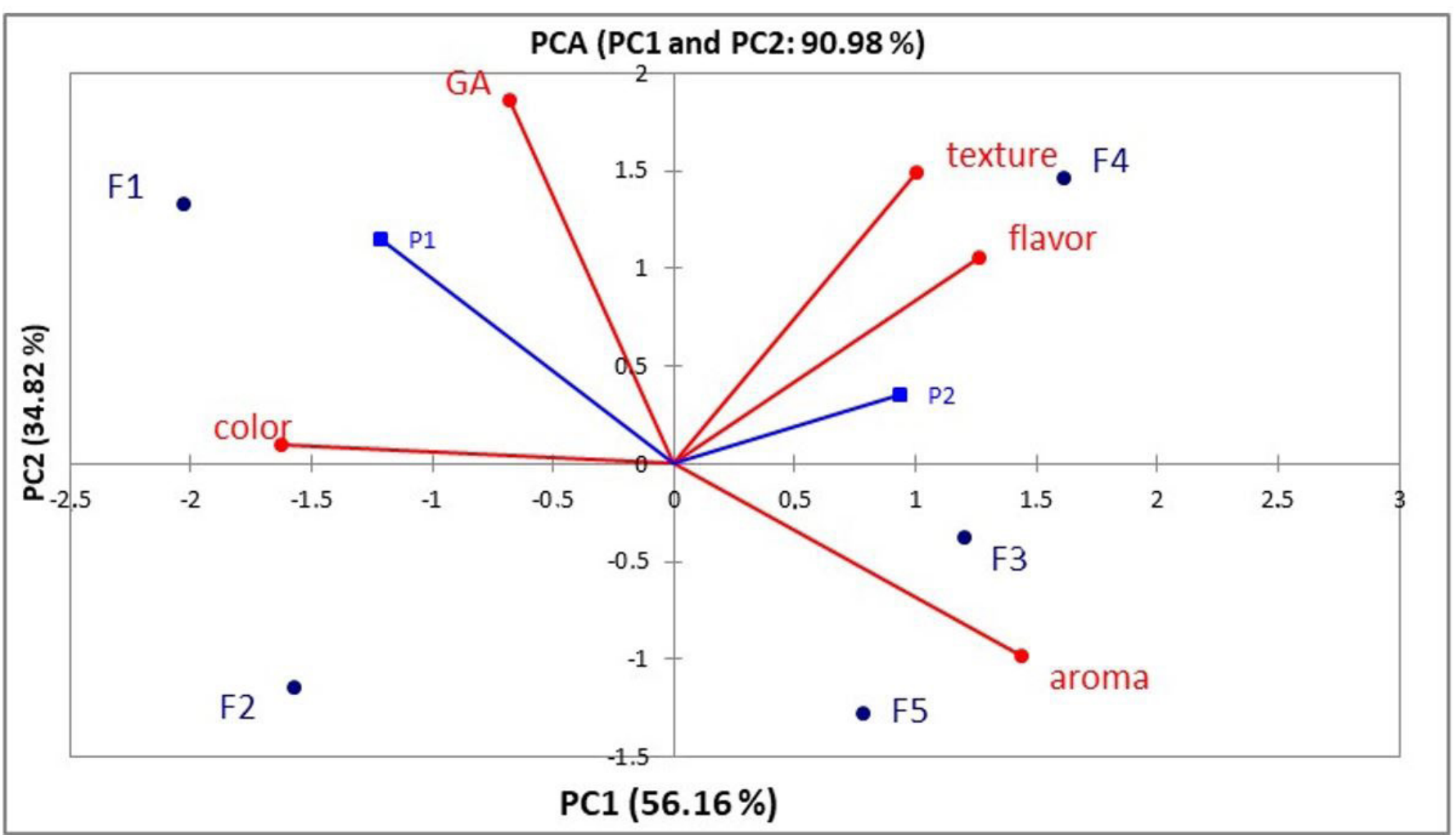

Figure 1. Principal component analysis in the acceptance of sensorial evaluated samples. PC1: Principal Component 1; PC2: Principal Component 2; P1 and P2 (Vectors that indicate the preference of the judges); F1, F2, F3, F4 and F5: Cereal bar formulations added with yellow araçá flour. GA: Global Appearance.

a highly positive relation of the use of yellow araçá flour, with panels highlighting flavor and texture attributes of the cereal bar, issues of extreme importance in quality.

Among the parameters evaluated, texture was the only one that showed a statistical difference $(\mathrm{p}<0.05)$ between F2 and F4 formulations. The average scores for the attributes such as color, flavor and overall appearance reached values greater than 7 for all formulations, being attributed to the concept of "I liked it moderately". Given this, texture can be considered as a threshold parameter in the acceptance of this product. However, it is noteworthy that the addition of $20 \%$ araçá flour received the best scores for the texture attribute, indicating high technological property, besides qualities in composition.
From the scores of the purchase intention test, it was not possible to establish differences that would define the purchase of a specific formulation. However, the preference test shows a difference between formulations F4 and F5. To further understand which attributes contributed to the preference of F4 by the panelists, a Principal Component Analysis (PCA) was performed (Figure 1).

The first component (PC1) showed $56.16 \%$ of variability among the samples, with $\mathrm{F} 4$ formulation obtaining more positive scores, represented by the sensory attributes of flavor and texture (Table 3), even though these attributes were not significant different when compared to other formulations. 
The variations between formulations can be explained, in part, by the Principal Component 1, but better evaluated when associated with Principal Component 2, being explained with $90.98 \%$ of the information contained in the scores of sensory attributes (Figure 1). According to Sodré et al. (2008) if, in an PCA, the sum of the percentages of the first two components accumulates more than $70 \%$ of the total variation, the analysis will satisfactorily explain the variability manifested between the evaluated samples.

In formulation F4, texture and flavor were determining factors for acceptance by the panelists. For the F1 formulation, the overall appearance was the factor that influenced the observations made by the judges. The vectors $\mathrm{P} 1$ and $\mathrm{P} 2$ indicate that all parameters considered in the sensory analysis explain the consumers' preference in relation to samples F1 and F4. Thus, it is observed that the texture and flavor attributes are positively related to each other in the acceptance and preference of sample F4.

Additional to the nutritional content, cereal bars with yellow araçá flour displayed good general acceptance, combining several sensorial attributes such as firmness, texture and preference (Zamora-Gasga et al., 2014; Oliveira et al., 2018). These important characteristic to the overall quality of food depend on many factors such as ingredients and their interactions with the rheological properties of the cereal bar (Foschia et al., 2013). The interaction among cereal ingredients can be improved by changes in the process. In this case, Severini et al. (2016) suggests that the rheological properties and their relation to the 3D food printing variables are of paramount importance for quality.

\subsection{Physical-chemical and mineral characterization of cereal bars}

Once formulation F4 reached better results in the sensorial analysis, physico-chemical and minerals characterization were carried out (Table 4).

Moisture is a parameter of product stability, being directly related to the development of microorganisms and sensorial characteristics of the final product. Lower values of moisture in cereal bars (10.70\%) where reported by Freitas \& Moretti, (2006).

Significant percentages of protein were found in the cereal bar added with yellow araça flour, comparing to other products developed with green banana flour (5.05\%; Tavares da Silva et al., 2014), acerola fruit (6.32\%; Marques et al. 2013), and commercially available cereal bars, whose values range from 5.00 to $7.00 \%$ (Tabela Brasileira de composição de alimentos, 2010).

The percentage of lipids (5.83\%) observed is similar to that contained in cereal bars sold on the market, with values ranging from 3.70 to $6.00 \%$, dependent on the ingredients in the composition, being considered a low-saturated fat food (1.50\%), free from trans fatty acids (Gutkoski et al., 2007; Marques et al., 2013). The World Health Organization (2002) has set as a goal the exclusion of these compounds in the composition of food, once the impact of trans fats on human health, due to their consumption, has been related to the development of chronic diseases.
Table 4. Physical-chemical and minerals characterization of cereal bars with yellow araçá flour, referring to the formulation with the best sensory preference (F4).

\begin{tabular}{|c|c|c|c|}
\hline \multicolumn{2}{|c|}{ Proximal Composition } & \multicolumn{2}{|c|}{ Main Minerals } \\
\hline Variables & Means & $\begin{array}{l}\text { Minerals* } \\
\left(\mathrm{mg} .100 \mathrm{~g}^{-1}\right)\end{array}$ & Means \\
\hline Moisture (\%) & $12.74 \pm 0.65$ & Iron & $2.56 \pm 0.11$ \\
\hline Proteins (\%) & $9.92 \pm 0.33$ & Magnesium & $73.71 \pm 0.98$ \\
\hline Lipids (\%) & $5.83 \pm 0.25$ & Potassium & $549.73 \pm 8.71$ \\
\hline Saturated fat (\%) & $1.50 \pm 0.31$ & Zinc & $1.18 \pm 0.07$ \\
\hline Trans fat (\%) & $\leq 0.01$ & Copper & $0.36 \pm 0.04$ \\
\hline Total fiber (\%) & $15.68 \pm 0.34$ & Phosphor & $254.88 \pm 2.31$ \\
\hline Ash (\%) & $2.16 \pm 0.05$ & & \\
\hline Carbohydrates (\%) & $53.6 \pm 0.79$ & & \\
\hline Caloric value ${ }^{*}$ & $307.13 \pm 3.39$ & & \\
\hline
\end{tabular}

${ }^{*} \mathrm{kcal} .100 \mathrm{~g}^{-1}$; Results are means of 3 replications with the respective estimates for standard deviation.

The amount of fiber in the developed product can be considered high, indicating that the consumption of a portion of $30 \mathrm{~g}$ (1 unit) of the cereal bar added with yellow araçá flour contributes with 12.30 to $18.80 \%$ of the recommended daily intake (RDI). This condition is well accepted by consumers, who associate the presence of this component as evidence of maintaining human health (Mauro et al. 2010).

The total carbohydrates content in the formulated cereal bar was $12.00 \%$ less than the formulation used as a reference (Freitas \& Moretti, 2006). This is basically due to adaptations in the constituents of the syrup solution or agglutination syrup, such as the reduction in the amounts of sugar and glucose syrup.

The average caloric value in the formulation was 307.13 $\mathrm{kcal}$ in $100 \mathrm{~g}$ of product, which indicates that when consuming a cereal bar ( $30 \mathrm{~g})$ added with yellow araçá flour the consumer will be ingesting $92.14 \mathrm{kcal}$, corresponding to $4.50 \%$ of the total indicated for daily calorie consumption based on a $2000 \mathrm{kcal}$ diet (Food and Drug Administration, 2018).

The consumption of foods that provide a minimum amount of minerals in the human diet is essential for the performance of the body's functions, such as the regulation of enzymatic activities and absorption of essential nutrients (Granato et al., 2009). The cereal bar developed can be considered a source of iron, magnesium, potassium and zinc. In addition, it has a high content of copper and phosphorus.

Thus, by consuming a $30 \mathrm{~g}$ portion of the cereal bar added with yellow araçá flour, made with ripe fruits, the consumer will satisfy $2.98 \%$ of the calcium recommended daily intake (RDI), as well as $12 \%$ of the copper RDI, $5.48 \%$ of iron RDI, $10.92 \%$ of phosphorus RDI, $8.5 \%$ of manganese RDI, $4.7 \%$ of potassium RDI, $0.66 \%$ of sodium RDI and $7.71 \%$ of zinc RDI. The absorption of minerals depends on the balance among nutrients. For example, vitamin A (b-carotene) and proteins promote the absorption of zinc, even inhibiting the inhibitory effects of phytate in the intestinal complex (Casgrain et al., 2010). 
Considering the good nutritional balance in yellow araçá flour, the cereal bar has indices that allow this quality.

The fatty acid composition in the formulated cereal bar, which contains $20 \%$ of yellow araçá flour made from ripe fruits and $15 \%$ of oat flakes, was analyzed to obtain the lipid profile of the product (Table 5). Eleven fatty acids were identified, of which three were saturated ( $16.73 \%$ of the total), two monounsaturated (50.64\% of the total) and six polyunsaturated (32.63\% of the total).

In terms of fatty acids composition, unsaturated fatty acids were the major contributors, contributing with more than $80 \%$ of the total content. Among unsaturated fatty acids, the polyunsaturated fatty acids (PUFAs), molecules that cannot be synthesized by the human body, being necessary to ingest it through the diet, corresponded to more than $32 \%$. These fatty acids can support cell integrity, prevent cardiovascular diseases and disorders, stimulate insulin release, inhibit vasoconstriction and inflammatory processes, and participate in fetal growth (Andrade \& Carmo, 2006).

The profile showed considerable amounts of linoleic and oleic acids (both unsaturated), which can contribute beneficially to human health (Covino et al., 2015). Among the monounsaturated fatty acids, the oleic acid presented the highest content (46.31\%), while among the polyunsaturated, the linoleic acid (18:2n-6) was the one presenting the highest content (22.93\%). In relation to linolenic acid, main fatty acid in the series omega-6, to be considered a "source", the legislation requires that at least $45 \%$ of the fatty acids present in the food correspond to the linolenic acid. This assumption also applies to the product elaborated in this work.

The major monounsaturated fat acid in the cereal bar was the oleic acid (18: 1n-9). The oleic acid (C18:1) has been identified as hypolipidemic, which acts by decreasing low density lipoproteins (LDL), presenting a protective effect against the development of atherosclerotic coronary disease. In addition, it is also used by the body as a preferred source of metabolizable energy for rapid growth (Zanqui et al., 2013; Li et al., 2020).

The ratio given by the content of polyunsaturated and saturated fatty acids (PUFA/AGS) has been used as a way to evaluate the nutritional value of oils and fats. This ratio in the formulated bar was around 1.95. According to the Department of Health and Social Security (Her Majesty's Stationery Office, 1984) values greater than 0.45 indicate that food is considered a good contributor to human health.

In general, in this study, the cereal bar added with yellow araçá flour demonstrates a great nutritional balance, besides a considerable acceptability in relation to the sensorial attributes. This food fits into a special profile, where is possible to alter its formulations with modifications in nutrient content, which can be suitable for use in different diets or for people with specific physiological and metabolic conditions (Brito et al., 2013). This cereal bar meets the health and food appeal, once it presents desirable nutrients such as fiber, unsaturated fatty acids, vitamins, minerals and bioactive compounds (Farinazzi-Machado et al., 2012).

As important as being a source of nutrients, it is necessary that this type of food presents highly bio-digestible nutrients.
Table 5. Composition, sum and ratio of fatty acids in cereal bars added with yellow araçá flour (Formulation F4).

\begin{tabular}{lrcr}
\hline Fatty acids & $\begin{array}{r}\text { Percentage of } \\
\text { peak area (\%) }\end{array}$ & \multicolumn{2}{c}{ Sums (\%) } \\
\hline C16:0 & $10.90 \pm 0.30$ & MUFA & $50.64 \pm 0.66$ \\
C18:0 & $4.82 \pm 0.17$ & PUFA & $32.63 \pm 0.15$ \\
C18:1n-9c & $46.31 \pm 0.62$ & SFA & $16.73 \pm 0.53$ \\
C18:2-n-6c & $22.93 \pm 1.06$ & n-9 & $50.64 \pm 0.66$ \\
C18:3n-3 & $0.85 \pm 0.09$ & n-6 & $28.02 \pm 0.72$ \\
C18:3n-6 & $3.10 \pm 0.29$ & $n-3$ & $1.65 \pm 0.28$ \\
C20:0 & $1.02 \pm 0.07$ & \multicolumn{2}{c}{ Ratio } \\
C20:3n-3 & $0.80 \pm 0.19$ & PUFA/SFA & $1.95 \pm 0.06$ \\
C20:4n-6 & $1.99 \pm 0.25$ & n-6/n-3 & $17.38 \pm 3.17$ \\
C22:1n-9 & $4.33 \pm 0.25$ & & \\
C22:2 & $2.96 \pm 0.41$ & & \\
\hline
\end{tabular}

MUFA: monounsaturated fatty acids; PUFA: polyunsaturated fatty acids (unsaturation $\geq 2$ ); SFA: saturated fatty acids. n-9: omega-9; n-6: omega-6; n-3: omega-6; PUFA/SFA: ratio between polyunsaturated and saturated fatty acids. n-6/n-3: ratio between omega- 6 and omega- 3 fatty acids. Sample triplicate means \pm standard deviation.

These (bioactive) compounds act directly by improving the growth of intestinal cells and probiotic microorganisms, promoting health benefits such as immunoregulatory activity and production of beneficial metabolites, like different types of vitamins including the B complex (Albuquerque et al., 2019).

Considering the sensitivity to degradation of polyphenols, which are partly bound to fibers and protected by polysaccharides, the proposed formulation was appropriate for the use of fruits. Thus, these compounds can be used as substrates in the fermentation process in the intestinal microbiota, producing various metabolites (e.g. folates), which provide health benefits (Chamorro et al., 2012). Another example of a cereal bar presenting functional properties is the one formulated with the addition of Allium fistulosum extract, related to an increase in the content of niacin and folic acid, which may have a protective action against liver oxidative stress, as well as an anti-obesity effect and metabolic disorders (Sung et al., 2014)

\section{Conclusion}

The drying process of ripe araçá fruits maintained or even increased the content of phenolic compounds and their antioxidant potential. A cereal bar showing good acceptance by the consuming public was made using 20\% of ripe yellow araçá flour and 15\% of oat flakes (F4 formulation). The product showed significant levels of nutrients, being considered a source of omega 6, iron, magnesium, potassium, zinc. In addition, presented low content of sodium and saturated fats, being free of trans fats. The formulated cereal bar can be considered functional due to its high fiber content.

\section{Acknowledgements}

The authors would like to thank, Araucária Foundation, CNPq and Federal University of Technology - Paraná (UTFPR) for funding and scholarship. 


\section{References}

Addinsoft (2015). XLSTAT 2015 (trial version). France: Addinsoft. Retrieved from http://http://www.xlstat.com/en/download.html//.

Ajila, C. M., \& Prasada Rao, U. J. S. (2013). Mango peel dietary fiber: composition and associated bound phenolics. Journal of Functional Foods, 5(1), 444-450. http://dx.doi.org/10.1016/j.jff.2012.11.017.

Albuquerque, M. A. C., Levit, R., Beres, C., Bedani, R., de Moreno de LeBlanc, A., Saad, S. M. I., \& LeBlanc, J. G. (2019). Tropical fruit by-products water extracts as sources of soluble fibers and phenolic compounds with potential antioxidant, anti-inflammatory, and functional properties. Journal of Functional Foods, 52, 724-733. http://dx.doi.org/10.1016/j.jff.2018.12.002.

Andrade, P. M. M., \& Carmo, M. G. T. (2006). Ácidos graxos n-3: um link entre eicosanóides, inflamação e imunidade. Revista MnMetabólica, 8(3), 135-143.

Assis, R. Q., Andrade, K. L., Gomes Batista, L. E., de Oliveira Rios, A., Dias, D. R., Ndiaye, E. A., \& de Souza, É. C. (2019). Characterization of mutamba (Guazuma ulmifolia LAM.) fruit flour and development of bread. Biocatalysis and Agricultural Biotechnology, 19, 101120. http://dx.doi.org/10.1016/j.bcab.2019.101120.

Association of Official Analytical Chemists - AOAC. (2010). Official methods of analysis of the Association of Official Analytical Chemists (18th ed.). Washington: AOAC.

Bligh, E. G., \& Dyer, W. J. (1959). A rapid method for total lipid extraction and purification. Canadian Journal of Biochemistry and Physiology, 37(8), 911-917. http://dx.doi.org/10.1139/o59-099. PMid:13671378.

Boffetta, P., Couto, E., Wichmann, J., Ferrari, P., Trichopoulos, D., Bueno-de-Mesquita, H. B., van Duijnhoven, F. J., Büchner, F. L., Key, T., Boeing, H., Nöthlings, U., Linseisen, J., Gonzalez, C. A., Overvad, K., Nielsen, M. R., Tjønneland, A., Olsen, A., Clavel-Chapelon, F., Boutron-Ruault, M. C., Morois, S., Lagiou, P., Naska, A., Benetou, V., Kaaks, R., Rohrmann, S., Panico, S., Sieri, S., Vineis, P., Palli, D., van Gils, C. H., Peeters, P. H., Lund, E., Brustad, M., Engeset, D., Huerta, J. M., Rodríguez, L., Sánchez, M. J., Dorronsoro, M., Barricarte, A., Hallmans, G., Johansson, I., Manjer, J., Sonestedt, E., Allen, N. E., Bingham, S., Khaw, K. T., Slimani, N., Jenab, M., Mouw, T., Norat, T., Riboli, E., \& Trichopoulou, A. (2010). Fruit and vegetable intake and overall cancer risk in the European Prospective Investigation into Cancer and Nutrition (EPIC). Journal of the National Cancer Institute, 102(8), 529-537. http://dx.doi.org/10.1093/jnci/djq072. PMid:20371762.

Brand-Williams, W., Cuvelier, M. E., \& Berset, C. (1995). Use of free radical method evaluate antioxidant activity. LebensmittelWissenschaft + Technologie, 28(1), 25-30. http://dx.doi.org/10.1016/ S0023-6438(95)80008-5.

Brasil. Ministério da Saúde. Conselho Nacional de Saúde. (2012, December 12). Aprova diretrizes e normas regulamentadoras de pesquisas envolvendo seres humanos (Resolução n. 466, de 12 de dezembro de 2012). Diário Oficial [da] República Federativa do Brasil.

Brito, A. L. B., Brito, L. R., Honorato, F. A., Pontes, M. J. C., \& Pontes, L. F. B. L. (2013). Classification of cereal bars using near infrared spectroscopy and linear iscriminant analysis. Food Research International, 51(2), 924-928. http://dx.doi.org/10.1016/j. foodres.2013.02.014.

Canuto, G. A., Xavier, A. A. O., Neves, L. C., \& Benassi, M. T. (2010). Caracterização físico-química de polpas de frutos da Amazônia e sua correlação com a atividade anti-radical livre. Revista Brasileira de Fruticultura, 32(4), 1196-1205. https://doi.org/10.1590/S010029452010005000122.
Casgrain, A., Collings, R., Harvey, L. J., Boza, J. J., \& Fairweather-Tait, S. J. (2010). Micronutrient bioavailability research priorities. The American Journal of Clinical Nutrition, 91(5), 1423S-1429S. http:// dx.doi.org/10.3945/ajcn.2010.28674A. PMid:20200267.

Cataneo, C. B., Caliari, V., Gonzaga, L. V., Kuskoski, E. M., \& Fett, R. (2008). Antioxidant activity and phenolic content of agricultural by-products from wine production. Semina: Ciências Agrárias, 29(1), 93-102. http://dx.doi.org/10.5433/1679-0359.2008v29n1p93.

Cavalcanti, R. N., Veggi, P. C., \& Meireles, M. A. A. (2011). Supercritical fluid extraction with a modifier of antioxidant compounds from jaboticaba (Myrciaria cauliflora) byoproducts: economic viability. Procedia Food Science, 1, 1672-1678. http://dx.doi.org/10.1016/j. profoo.2011.09.247.

Chamorro, S., Viveros, A., Alvarez, I., Vega, E., \& Brenes, A. (2012). Changes in polyphenol and polysaccharide content of grape seed extract and grape pomace after enzymatic treatment. Food Chemistry, 133(2), 308-314. http://dx.doi.org/10.1016/j.foodchem.2012.01.031. PMid:25683400.

Covino, R., Monteiro, A. R. G., Scapim, M. R. S., Marques, D. R., Benossi, L., \& Monteiro, C. C. F. (2015). Manufacturing cereal bars with high nutritional value through experimental design. Acta Scientiarum. Technology, 37(1), 149-155. http://dx.doi.org/10.4025/ actascitechnol.v37i1.20732.

Dalla Nora, C., Danelli, D., Souza, L. F., Rios, A. D. O., Jong, E. V. D., \& Flôres, S. H. (2014). Protective effect of guabiju (Myrcianthes pungens (O. Berg) D. Legrand) and red guava (Psidium cattleyanum Sabine) against cisplatin-induced hypercholesterolemia in rats. Brazilian Journal of Pharmaceutical Sciences, 50(3), 483-491. http:// dx.doi.org/10.1590/S1984-82502014000300006.

Damiani, C., Silva, F. A., Asquieri, E. R., Lage, M. E., \& Vilas Boas, E. V. B. (2012). Antioxidant potential of Psidium guinnensis sw. jam during storage. Pesquisa Agropecuária Tropical, 42(1), 90-98. http:// dx.doi.org/10.1590/S1983-40632012000100013.

Dantas, A. L., Silva, S. M., Lima, M. A. C., Dantas, R. L., \& Mendonça, R. M. N. (2013). Bioactive compounds and antioxidant activity during maturation of strawberry guava fruit. Ciência Agronômica, 44(4), 805-814. http://dx.doi.org/10.1590/S180666902013000400018.

Farinazzi-Machado, F. M. V., Barbalho, S. M., Oshiiwa, M., Goulart, R., \& Pessan, O. Jr. (2012). Use of cereal bars with quinoa (Chenopodium quinoa W.) to reduce risk factors related to cardiovascular diseases. Food Science and Technology (Campinas), 32(2), 239-244. http:// dx.doi.org/10.1590/S0101-20612012005000040.

Fasolin, L. H., Almeida, G. C., Castanho, P. S., \& Netto-Oliveira, E. R. (2007). Biscoitos produzidos com farinha de banana: avaliações química, física e sensorial. Food Science and Technology (Campinas), 27(3), 524-529. http://dx.doi.org/10.1590/S010120612007000300016.

Food and Drug Administration - FDA. (2018). How to understand and use the nutrition facts label. USA: FDA. Retrieved from https:// www.fda.gov/ForConsumers/ConsumerUpdates/ucm274593. htm\# overview

Foschia, M., Peressini, D., Sensidoni, A., \& Brennan, C. S. (2013). The effects of dietary fibre addition on the quality of common cereal products. Journal of Cereal Science, 58(2), 216-227. http://dx.doi. org/10.1016/j.jcs.2013.05.010.

Freitas, D. G. C., \& Moretti, R. H. (2006). Caracterização e avaliação sensorial de barra de cereais funcional de alto teor protéico e vitamínico. Food Science and Technology, 26(2), 318-324. http:// dx.doi.org/10.1590/S0101-20612006000200014. 
Granato, D., Wiecheteck, F. P., \& Ribani, R. (2009). Mineral composition of cookies developed with almond or peanut flours supplemented with iron. Pesquisa Agropecuária Tropical, 39(2), 92-97.

Gutkoski, L. C., Bonamigo, J. M. A., Teixeira, D. M. F., \& Pedó, I. (2007). Desenvolvimento de barras de cereais à base de aveia com alto teor de fibra alimentar. Food Science and Technology, 27(2), 355-363. http://dx.doi.org/10.1590/S0101-20612007000200025.

Her Majesty's Stationery Office - HMSO, \& Departament of Health and Social Security. (1984). Diet and cardiovascular disease (Report on Health and Social Subjects, No. 28). London: HMSO.

Li, D., Tong, Y., \& Li, Y. (2020). Associations between dietary oleic acid and linoleic acid and depressive symptoms in perimenopausal women: the study of Women's Health Across the Nation. Nutrition (Burbank, Los Angeles County, Calif.), 71, 110602. http://dx.doi. org/10.1016/j.nut.2019.110602. PMid:31837641.

Lim, Y. Y., \& Murtijaya, J. (2007). Antioxidant properties of Phyllanthus amarus extracts as affected by different drying methods. LebensmittelWissenschaft + Technologie, 40(9), 1664-1669. http://dx.doi. org/10.1016/j.lwt.2006.12.013.

Marques, T. R., Corrêa, A. D., Lino, J. B. D. R., Abreu, C. M. P. D., \& Simão, A. A. (2013). Chemical constituents and technological functional properties of acerola (Malpighia emarginata DC.) waste flour. Food Science and Technology (Campinas), 33(3), 526-531. http://dx.doi. org/10.1590/S0101-20612013005000085.

Marquetti, C., Santos, T. B., Kaipers, K. F. C., Böger, B. R., Tonial, I. B., Wagner, A. Jr., Lucchetta, L., \& Prado, N. V. (2018). Jaboticaba skin flour: analysis and sustainable alternative source to incorporate bioactive compounds and increase the nutritional value of cookies. Food Science and Technology (Campinas), 38(4), 629-638. http:// dx.doi.org/10.1590/fst.06717.

Mauro, A. K., Silva, V. L. M., \& Freitas, M. C. J. (2010). Caracterização física, química e sensorial de cookies confeccionados com farinha de talo de couve (FTC) e farinha de talo de espinafre (FTE) ricas em fibra alimentar. Food Science and Technology (Campinas), 30(3), 719-728. http://dx.doi.org/10.1590/S0101-20612010000300024.

Medina, A. L., Haas, L. I. R., Chaves, F. C., Salvador, M., Zambiazi, R. C., Da Silva, W. P., Nora, L., \& Rombaldi, C. V. (2011). Araçá (Psidium cattleianum Sabine) fruit extracts with antioxidant and antimicrobial activities and antiproliferative effect on human cancer cells. Food Chemistry, 128(4), 916-922. http://dx.doi.org/10.1016/j. foodchem.2011.03.119.

Neri-Numa, I. A., Carvalho-Silva, L. B., Morales, J. P., Malta, L. G., Muramoto, M. T., Ferreira, J. E. M., de Carvalho, J. E., Ruiz, A. L. T. G., Maróstica Junior, M. R., \& Pastore, G. M. (2013). Evaluation of the antioxidant, antiproliferative and antimutagenic potential of araçá-boi fruit (Eugenia stipitata Mc Vaugh-Myrtaceae) of the Brazilian Amazon Forest. Food Research International, 50(1), 70-76. http://dx.doi.org/10.1016/j.foodres.2012.09.032.

Oliveira, L. C., Alencar, N. M. M., \& Steel, C. J. (2018). Improvement of sensorial and technological characteristics of extruded breakfast cereals enriched with whole grain wheat flour and jabuticaba (Myrciaria cauli flora) peel. Lebensmittel-Wissenschaft + Technologie, 90, 207-214. http://dx.doi.org/10.1016/j.lwt.2017.12.017.

Osborne, D. R., \& Voogt, P. (1978). The analysis of nutrient in foods. London: Academic Press.

Pereira, M. C., Steffens, R. S., Jablonski, A., Hertz, P. F., de O. Rios, A., Vizzotto, M., \& Flôres, S. H. (2012). Characterization and antioxidant potential of brazilian fruits from the myrtaceae family. Journal of Agricultural and Food Chemistry, 60(12), 3061-3067. http://dx.doi. org/10.1021/jf205263f. PMid:22397467.
Queiroz, C., Lopes, M. L. M., Fialho, E., \& Valente-Mesquita, V. L. (2011). Changes in bioactive compounds and antioxidant capacity of fresh-cut cashew apple. Food Research International, 44(5), 1459146. http://dx.doi.org/10.1016/j.foodres.2011.03.021.

Rufino, M. S. M., Alves, R. E., Brito, E. S., Morais, S. M., Sampaio, C. G., Pérez-Jiménez, J., \& Saura-Calixto, F. D. (2006). Metodologia científica: determinação da atividade antioxidante total em frutas pelo método de redução do ferro (FRAP) (Comunicado técnico online, No. 125). Fortaleza: Embrapa Agroindústria Tropical. Retrieved from https://ainfo.cnptia.embrapa.br/digital/bitstream/ CNPAT-2010/11964/1/cot-125.pdf

Rufino, M. S. M., Alves, R. E., Brito, E. S., Morais, S. M., Sampaio, C. G., Pérez-Jiménez, J., \& Saura-Calixto, F. D. (2007). Metodologia científica: determinação da atividade antioxidante total em frutas pela captura do radical livre DPPH. (Comunicado técnico online, No. 127). Fortaleza: Embrapa Agroindústria Tropical. Retrieved from https://ainfo.cnptia.embrapa.br/digital/bitstream/CNPAT/10224/1/ Cot_127.pdf

Santos, D., \& Meireles, M. A. (2009). Jabuticaba as a source of functional pigments. Pharmacognosy Reviews, 3(5), 137. Retrieved from https://www.phcogrev.com/sites/default/files/ PhcogRev-3-5-137.pdf

Selani, M. M., Bianchini, A., Ratnayake, W. S., Flores, R. A., Massarioli, A. P., de Alencar, S. M., \& Canniatti Brazaca, S. G. (2016). Physicochemical, functional and antioxidant properties of tropical fruits co-products. Plant Foods for Human Nutrition (Dordrecht, Netherlands), 71(2), 137-144. http://dx.doi.org/10.1007/s11130016-0531-z. PMid:26984339.

Selani, M. M., Brazaca, S. G., Dos Santos Dias, C. T., Ratnayake, W. S., Flores, R. A., \& Bianchini, A. (2014). Characterization and potential application of pineapple pomace in an extruded product for fibre enhancement. Food Chemistry, 163, 23-30. http://dx.doi. org/10.1016/j.foodchem.2014.04.076. PMid:24912691.

Severini, C., Derossi, A., \& Azzollini, D. (2016). Variables affecting the printability of foods: Preliminary tests on cereal-based products. Innovative Food Science \& Emerging Technologies, 38, 281-291. http://dx.doi.org/10.1016/j.ifset.2016.10.001.

Singleton, V. L., Orthofer, R., \& Lamuela-Raventós, R. M. (1999). Analysis of total phenols and other oxidation substrates and antioxidants by means of folin-ciocalteu reagent. Methods in Enzymology, 299, 152178. http://dx.doi.org/10.1016/S0076-6879(99)99017-1.

Sodré, G. D. S., Carvalho, C. A. L. D., Fonseca, A. A. O., Alves, R. M. D. O., \& Souza, B. D. A. (2008). Sensorial profile and acceptability of stingless bee honey submitted to conservation processes. Food Science and Technology (Campinas), 28, 72-77. http://dx.doi.org/10.1590/ S0101-20612008000500012.

Sung, Y. Y., Kim, S.-H., Kim, D. S., Park, S. H., Yoo, B. W., \& Kim, H. K. (2014). Nutritional composition and anti-obesity effects of cereal bar containing Allium fistulosum (welsh onion) extract. Journal of Functional Foods, 6, 428-437. http://dx.doi.org/10.1016/j. jff.2013.11.009.

Tabela Brasileira de composição de alimentos - TBCA. (2010). Departamento de Alimentos e Nutrição experimental. Universidade de São Paulo. Retrieved from http://www.fcf.usp.br.

Tavares da Silva, S., Araújo dos Santos, C., Marvila Girondoli, Y., Mello de Azeredo, L., Fernando de Sousa Moraes, L., Keila Viana Gomes Schitini, J., Flávio C de Lima, M., Cristina Lopes Assis Coelho, R., \& Bressan, J. (2014). Women with metabolic syndrome improve antrophometric and biochemical parameters with green banana flour consumption. Nutrición Hospitalaria, 
29(5), 1070-1080. http://dx.doi.org/10.3305/nh.2014.29.5.7331. PMid:24951987.

Toledo, N. M. V., Nunes, L. P., da Silva, P. P. M., Spoto, M. H. F., \& Canniatti-Brazaca, S. G. (2017). Influence of pineapple, apple and melon by-products on cookies: physicochemical and sensory aspects. International Journal of Food Science \& Technology, 52(5), 1185-1192. http://dx.doi.org/10.1111/ijfs.13383.

Veggi, P. C., Santos, D. T., \& Meireles, M. A. A. (2011). Anthocyanin extraction from Jaboticaba (Myrciaria cauliflora) skins by different techniques: economic evaluation. Proc. Food Sc, 1, 1725-1731. http:// dx.doi.org/10.1016/j.profoo.2011.09.254.

World Health Organization - WHO (2002). Reducing Risks, Promoting Healthy Life. The world health report. Geneva. Retrieved from http:// www.who.int/whr/2002/en/whr02_en.pdf?ua=1.
Zamora-Gasga, V. M., Bello-Pérez, L. A., Ortíz-Basurto, R. I., Tovar, J., \& Sáyago-Ayerdi, S. G. (2014). Granola bars prepared with Agave tequilana ingredients: Chemical composition and invitro starch hydrolysis. Lebensmittel-Wissenschaft + Technologie, 56(2), 309-314. http://dx.doi.org/10.1016/j.lwt.2013.12.016.

Zanqui, A. B., Maruyama, S. A., Barilli, D. J., Ribeiro, S. A. O., Gomes, S. T. M., Visentainer, J. V., Souza, N. E. D., Boscolo, W. R., \& Matsushita, M. (2013). Incorporation of conjugated linoleic and alpha linolenic fatty acids into Pimedolus maculatus fillets. Food Science and Technology (Campinas), 33(3), 532-540. http://dx.doi.org/10.1590/S0101-20612013005000066.

Zhishen, J., Mengcheng, T., \& Jianming, W. (1999). The determination of flavonoid contents in mulberry and their scavenging effects on superoxide radical. Food Chemistry, 64(4), 555-559. http://dx.doi. org/10.1016/S0308-8146(98)00102-2. 